\section{Comparison of Integrated and Conventional Production of Young Nonbearing Apple Orchards}

\author{
Maria Borovinova $^{1}$ - Ivanova Iliyana ${ }^{2}$ \\ ${ }^{1}$ Institute of Agriculture, Kyustendil, Bulgaria \\ ${ }^{2}$ National Agricultural Advisory Service, \\ Office in Kyustendil, Bulgaria \\ iz_kn@infotel.bg
}

\section{SUMMARY}

The large number of pesticide applications in apple orchards creates serious problems with pesticide residues and their side effects on beneficial organisms, the environment and human health. This is the reason behind the search for new systems for apple protection.

The investigations were made in apple orchards of the Institute of Agriculture at Kyustendil, during the period from 1997-1999. Three scab resistant cultivars grafted on rootstocks MM106 were planted in 1996. The orchard was divided into four plots. Two plots were treated as "conventionally” and the other two were treated as "integrated" according to the general principles, rules and standards of integrated apple production.

The key disease during the experimental period was powdery mildew, which can be controlled only with pruning of infected clusters and shoots during the first three years after planting. The key pests in the orchard during the nonbearing period were the green apple aphid and San Jose scale. In the integrated plant protection system, it is possible to reduce the number of insecticide treatments depending on the density of the main pests.

Keywords: integrated fruit production, apple, pests, diseases, economical threshold

\section{INTRODUCTION}

The soil, climatic and topographical conditions in many regions of Bulgaria are favorable for apple growing and production of high quality fruits. It is impossible to grow trees and have high quality and quantity production without plant protection practices. The large number of pesticide applications (10-16 in a growing season) creates serious problems with pesticide residues and their side effects on beneficial organisms, the environment and human health. This is the reason for the search for new environmentally-friendly systems for apple protection. These new systems are e.g. integrated and organic production systems, which are being investigated in the case of apple diseases, pest and weeds (van der Scheer, 1980; Alston, 1989; Dickler and Schaffermeyer, 1993; Blommers, 1994; Sutton, 1996; Grauslund and Bertelsen, 1996; Holb and Heijne, 2001; Holb et al., 2001). Several points of integrated and organic production systems are well qualified (Anonymous, 1989; Dickler, 1990; Dickler and Schaffermeyer, 1991; Cross and Dickler, 1994; Avilla, 1996; Grauslund and Bertelsen, 1996; Berrie and Cross, 1996; El Titi et al., 1996; Holb et al., 2003b), however, further development of plant protection is still needed for both environmentallyfriendly production systems in apple growing (Cross, 1993; Cross et al., 1996; Holb et al., 2003b).

The aim of our study was to compare the effect of conventional and integrated plant protection systems on incidences of several plant diseases and pests. Investigations were made in three consecutive seasons on three apple cultivars.

\section{MATERIAL AND METHODS}

The investigations were made on an experimental apple orchard (1 ha) of the Institute of Agriculture at Kyustendil, during the period from 1997-1999. Three scab resistant cultivars - Prima, Florina and Erwin Baur grafted on rootstocks MM106 were planted in 1996. The orchard was divided into four plots. Two plots were treated „conventionally” with a normal pesticide programme and the other two plots ,integrated" according to the general principles, rules and standards of integrated apple production (Dickler and Schaffermeyer, 1991; Cross and Dickler, 1994; Pelov et al., 1996). The monitoring of pests and diseases and assessment of their density were done every two weeks. Pesticides used in the conventional system were: Bayleton WP 25\% (triadimefon), Champion WP 77\% (copper hydroxide), Agria 1050 (fenitrotion), Erifan 48 EK (chlorpyrifos-ethil), Reldan 50 EK (chlorpyrifos-methil), Nurele Dursban (cypermethrin + chlorpyrifos-ethil), Croneton (ethiofencarp), mineral oil, and in the integrated system the applied chemicals were Bayleton WP 25\% (triadimefon), Champion WP 77\% (copper hydroxide), Alsystin 25 (triflumuron), Agria 1050 (fenitrotion), Reldan 50 EK (chlorpyrifos-methil), Croneton (ethiofencarp), and mineral oil. Protective treatments were made with copper-based fungicides to protect trees against fire blight (Erwinia amylovora (Burrill) Winslow) in both plant protection systems. Fire blight is common in our apple growing region.

Incidences of all apple diseases and pests were assessed in all of the three growing seasons. Assessed diseases and pests, their economic threshold levels and number of treatments during the examined periods can be seen in Table 1 . 
Diseases and pests, their economic threshold levels and number of treatments during the nonbearing period (1997-1999, Kyustendil, Bulgaria)

\begin{tabular}{|c|c|c|c|c|c|c|c|}
\hline \multirow{2}{*}{ Diseases and insects } & \multirow{2}{*}{ Economical threshold level } & \multicolumn{3}{|c|}{ Conventional } & \multicolumn{3}{|c|}{ Integrated } \\
\hline & & 1997 & 1998 & 1999 & 1997 & 1998 & 1999 \\
\hline Podosphaera leucotricha & & 0 & 0 & 5 & 0 & $\begin{array}{l}\text { Mechanical } \\
\text { control }\end{array}$ & $\begin{array}{c}\text { Mechanical } \\
\text { control }\end{array}$ \\
\hline Erwinia amylovora & & $\begin{array}{c}1 \\
\text { preventive }\end{array}$ & $\begin{array}{c}2 \\
\text { preventive }\end{array}$ & $\begin{array}{c}1 \\
\text { preventive }\end{array}$ & $\begin{array}{c}1 \\
\text { preventive }\end{array}$ & $\begin{array}{c}2 \\
\text { preventive }\end{array}$ & $\begin{array}{c}1 \\
\text { preventive }\end{array}$ \\
\hline Laspeyresia pomonella $\mathrm{L}$. & $1-2$ eggs (penetration) $/ 100$ fruits & 0 & 0 & 2 & 0 & 0 & 1 \\
\hline $\begin{array}{l}\text { Adoxophyes orana } \mathrm{Hb} \text {; } \\
\text { Tmetocera ocellana } \mathrm{F} . ; \\
\text { Hedya nubiferana Haw.; } \\
\text { Archips rosana L.; } \\
\text { Archips xylosteana } \mathrm{L} . \\
\end{array}$ & 4-10 caterpillars/100 clusters & 0 & 0 & 1 & 0 & 0 & $\begin{array}{c}\text { Mechanical } \\
\text { control }\end{array}$ \\
\hline Cemiostoma scitella Zell. & $\begin{array}{l}\text { 8-10 moths } / 100 \text { bearing shoots or: } \\
2 \text { eggs (mines)/leaf }\end{array}$ & 0 & 1 & 1 & 0 & 1 & 1 \\
\hline $\begin{array}{l}\text { Stigmella malella Stt. } \\
\text { Lithocolletis blancardella F.; } \\
\text { Lithocolletis corylifoliella Hw.; } \\
\text { Lyonetia clerkella L. }\end{array}$ & $\begin{array}{l}\text { 3-4 eggs (mines)/leaf } \\
4 \text { eggs (mines)/leaf }\end{array}$ & & & & & & \\
\hline Phyllobius oblongus L. & & 0 & 0 & 0 & 0 & 0 & 0 \\
\hline Hoplocampa testudinea Klug. & $\begin{array}{l}2-3 \text { wasps } / 100 \text { bearing branches or } \\
3-5 \text { eggs } / 100 \text { flowers }\end{array}$ & 0 & 0 & 0 & 0 & 0 & 0 \\
\hline Synanthedon myopaeformis Borkh. & & 0 & 0 & 0 & 0 & 0 & 0 \\
\hline Zeuzera pyrina $\mathrm{L}$. & & 0 & 0 & 0 & 0 & 0 & 0 \\
\hline Stephanitis pyri $\mathrm{F}$. & & 0 & 0 & 0 & 0 & 0 & 0 \\
\hline Aphis pomi De Geer. & $\begin{array}{l}10-15 \text { colonies } / 100 \text { shoots before } \\
\text { blooming and the end of the vegetation, } \\
8-10 \text { colonies } / 100 \text { shoots after blooming }\end{array}$ & 1 & 1 & 1 & 1 & 1 & 1 \\
\hline Diaspidiotus perniciosus Curt. & & 0 & 3 & 4 & 0 & 3 & 3 \\
\hline Panonychus ulmi Koch. & $\begin{array}{l}\text { April }-2-3 \text {; blooming }-4-5 \text {, middle of } \\
\text { July }- \text { September } 1-2 \text { moving forms/leaf }\end{array}$ & 0 & 0 & 0 & 0 & 0 & 0 \\
\hline Tetranychus urticae Koch. & & 0 & 0 & 0 & 0 & 0 & 0 \\
\hline
\end{tabular}

\section{RESULTS AND DISCUSSION}

\section{Incidence of plant diseases}

Permanent disease on the three cultivars was powdery mildew (Podosphaera leucotricha (Ell. et Ev.) Salmon). Cultivars Prima, Florina and Erwin Baur were slightly infected with powdery mildew in both plant protection systems during the examined periods (Table 2). The results were similar to results of Borovinova (1994) made in Kyustendil during 1992-1994. Holb et al. (2001) also found low disease incidence in Hungary in integrated apple orchards on six apple cultivars, including two resistant ones. In other studies, van der Scheer (1980) and Holb et al. (2003a) found low disease incidence of apple scab on scab susceptible apple cultivar Jonagold in a Dutch integrated apple orchard. Moreover, strong relationships were shown between disease incidence and severity measurements and predictive models were given to forecast scab on leaf and fruit (Holb et al., 2003a). In our study, disease was controlled with five fungicide applications in the conventional systems and with pruning of infected clusters and shoots in the integrated systems. Regardless of absence of treatments in the integrated system, the damage by powdery mildew was under the economic threshold level on all the three cultivars (Table 2). Other apple diseases were not found on the investigated apple cultivars. These results were similar to those of van der Scheer (1980) and Holb et al. (2001).

Per cent of infected buds and disease incidence of leaves of powdery mildew (Podosphaera leucotricha) 1997-1999 (Kyustendil, Bulgaria)

\begin{tabular}{|l|l|l|r|r|r|r|r|}
\hline \multirow{2}{*}{ Disease control } & \multirow{2}{*}{ Cultivars } & \multicolumn{3}{|c|}{ Percent of infected buds } & \multicolumn{3}{c|}{ Disease incidence on leaves (\%) } \\
\cline { 2 - 8 } & & $\mathbf{1 9 9 7}$ & $\mathbf{1 9 9 8}$ & $\mathbf{1 9 9 9}$ & $\mathbf{1 9 9 7}$ & \multicolumn{1}{c|}{$\mathbf{1 9 9 8}$} & 1.40 \\
\hline \multirow{3}{*}{ Conventional } & Prima & Separate & 0.47 & 3.12 & Separate & 0.60 \\
\cline { 2 - 8 } & Florina & Separate & 0.22 & 0.59 & Separate & 1.50 & 2.25 \\
\cline { 2 - 8 } & Erwin Baur & Separate & 0.00 & 0.00 & Separate & 0.10 & 0.20 \\
\hline \multirow{3}{*}{ Integrated } & Prima & Separate & 0.45 & 4.14 & Separate & 3.05 & 1.20 \\
\cline { 2 - 8 } & Florina & Separate & 1.40 & 0.68 & Separate & 2.00 & 4.00 \\
\cline { 2 - 8 } & Erwin Baur & Separate & 0.35 & 0.00 & Separate & 0.45 & 0.05 \\
\hline
\end{tabular}




\section{Incidence of plant pests}

During the examined period, the following pests were found in the experimental orchard: green apple aphid (Aphis pomi De Geer.), San Jose scale (Diaspidiotus perniciosus Curt.), leafrollers such as Adoxophyes orana Hb., Tmetocera ocellana F., Hedya nubiferana Haw., Archips rosana L., Archips xylosteana L.; leaf miners such as Cemiostoma scitella Zell., Stigmella malella Stt., Lithocolletis blancardella F., Lithocolletis corylifoliella Hw., Lyonetia clerkella L., Phyllobius oblongus L.; codling moth (Cydia (Laspeyresia) pomonella L.), apple sawfly (Hoplocampa testudinea Klug.), apple clearwing (Synanthedon myopaeformis Bork.), leopard moth (Zeuzera pyrina L.), lace pear bug (Stephanitis pyri F.), European red mite (Panonychus ulmi Koch.), two-spotted spider mite (Tetranychus urticae Koch., Tetranychus viennensis Zacher) Table 1.

The presence of aphids in the conventional production system was low, but the density was over the accepted threshold level in the integrated plant protection system.

In the first year, aphids had to be controlled by approved insecticides in the integrated orchard. A few separate trees were attacked and severely damaged by leopard moth (Zeuzera pyrina L.) and they were uprooted. During the second year, five insecticide treatments were applied against aphids, leaf miners and San Jose scale in order to reduce their number under the economic threshold level. In the third year, seven insecticide treatments were applied in the conventional and six in the integrated production systems against aphids, San Jose scale, leaf miners and leaf rollers. The presence of separate flowers and fruits led up to a special treatment against codling moth (Cydia (Laspeyresia) pomonella L.). In the three years, one treatment against leaf rollers was saved in integrated plant protection because their density was below the economic threshold level. Similar results of damage caused by pests were obtained in several other European integrated orchards (Bloomers, 1994; Berrie and Cross, 1996; Grauslund and Bertelsen, 1996).

\section{CONCLUSIONS}

The key disease during the experimental period was powdery mildew, which could be effectively controlled when fungicide treatments were combined with pruning of infected clusters and shoots during the first three years after planting.

The key pests in the integrated orchard during the nonbearing period were the green apple aphid and San Jose scale. These pests could be controlled by integrated plant protection methods. In the integrated control system, it is possible to reduce the number of insecticide treatments depending on the density of the main pests.

\section{REFERENCES}

Alston, F. H. (1989): Breeding pome fruits with stable resistances to diseases. 2. Selection techniques and breeding strategy, IOBC/WPRS Bulletin, Bulletin WPRS/SROP, 12. 6. 90-99.

Anonymous (1989): Basic standards of organic agriculture. IFOAM, Tholey-Theley, BRD

Avilla, J. (1996): Task and position of the IOBC/WPRS IPCommission; an evaluation of the role of IP Guidelines I-III. IOBC/WPRS Bulletin, 19. 4. 11-16.

Berrie, A. M.-Cross, V. J. (1996): An evaluation of plant protection practices according to IFP guidelines compared to current commercial practice. IOBC/WPRS Bull., 19. 4. 17-27.

Blommers, L. H. M. (1994): Integrated pest management in European apple orchards. Annual Review of Entomology, 39. 213-241.

Borovinova, M. (1994): Susceptibility of 9 scab resistant apple varieties to powdery mildew /Podosphaera lecotricha (Ell et Ev) Salmon/. Plant Science, 31. 7-10. 132-134.

Cross, J. V. (1993): An overview of the second ISHS International Symposium on Integrated Fruit Production. Acta Horticulturae, 347. 375-377.

Cross, J. V.-Dickler, E. (1994): Guidelines for integrated production of pome fruits in Europe. Technical Guideline III IOBC Bulletin, 17. 9. 1-40.

Cross, V. J.-Bonauer, A.-Bondio, V.-Clemente, J.-Denis, J.Grauslund, J.-Huguet, C.-Jörg, E.-Koning, S.-Kvale, A.Malavolta, C.-Marcelle, R.-Morandell, I.-Oberhofer, H.Pontalti, F.-Rossini, M.-Schenk, A.-de Schaetzen, C.Vilajeliu, M. (1996): The current status of integrated fruit production in Western Europe and its achievements. IOBC/WPRS Bull., 19. 4. 1-10.

Dickler, E. (1990): Guidelines and labels defining integrated fruit production in European countries. IOBC/WPRS Bulletin, 13. 8. 76.

Dickler, E.-Schafermeyer, S. (1993): Guidelines for integrated production of pome fruits in Europe. Acta Horticulturae, 347. 83-96.
Dickler, E.-Schaffermeyer, S. (1991): General principles, guidelines and standards for integrated production of pome fruits in Europe. IOBC/WPRS Bulletin, 24. 3. 1-66.

El Titi, A.-Boller, E. F.-Gendrier, J. P. (1993): Integrated production. Principles and technical guidelines, IOBC/WPRS Bulletin, 16. 1.96.

Grauslund, J.-Bertelsen, M. (1996): Comparison of integrated and conventional production of apples. IOBC/WPRS Bulletin, Bulletin OILB/SROP, 19. 4. 75-79.

Holb, I. J.-Gonda, I.-Bitskey, K. (2001): Pruning and incidences of diseases and pests in environmentally oriented apple growing systems: some aspects. International Journal of Horticultural Science, 7. 1. 24-29.

Holb, I. J.-Heijne, B. (2001): Evaluating primary scab control in organic apple production. Gartenbauwissenschaft-The European Journal for Horticultural Science, 66. 5. 254-261.

Holb, I. J.-Heijne, B.-Jeger, M. J. (2003a): Summer epidemics of apple scab: the relationship between measurements and their implications for the development of predictive models and threshold levels under different disease control regimes. Journal of Phytopathology, 151. 6. 335-343.

Holb, I. J.-Jong, de P. F.-Heijne, B. (2003b): Efficacy and phytotoxicity of lime sulphur in organic apple production. Annals of Applied Biology, 142. 2. 225-233.

Pelov, V.-Angelova, R.-Karov, S.-Borovinova, M. (1996): General principles, rules and standards for obtaining apple integrated production. International Symposium; „Integrated plant protection in the viticulture and fruit culture", Sandansky, Bulgaria, September 23-27, Abstracts

Sutton, T. B. (1996): Changing options for the control of deciduous fruit tree diseases. Annual Review of Phytopathology, 34. 527-547.

van der Scheer, H. A. Th. (1980): Threshold of economic injury for apple powdery mildew and scab. In: Integrated control of insect pest in the Netherlands, pp. 49-52. Pudoc, Wageningen 